Support information for

\title{
Mn-Rich Phosphate Cathodes for Na-lon Batteries with Superior Rate Performance
}

Chunliu Xua, b†, Ruijuan Xiao ${ }^{c \dagger}$, Junmei Zhao a, d ${ }^{*}$, Feixiang Ding ${ }^{c}$, Yang Yang ${ }^{c}$, Xiaohui Rong ${ }^{c}$, Xiaodong Guo ${ }^{\text {*}}$, Chao Yang ${ }^{a}$, Huizhou Liu ${ }^{a}$, Benhe Zhong ${ }^{b}$ and Yong-Sheng $\mathrm{Hu}^{\mathrm{c}}$

a CAS Key Laboratory of Green Process and Engineering, State Key Laboratory of Biochemical Engineering, Institute of Process Engineering, Chinese Academy of Sciences, Beijing 100190, China. "E-mail: jmzhao@ipe.ac.cn

b School of Chemical Engineering, Sichuan University, Chengdu 610065, P. R. China. *E-mail: xiaodong2009@163.com

c Key Laboratory for Renewable Energy, Beijing Key Laboratory for New Energy Materials and Devices, Beijing National Laboratory for Condensed Matter Physics, Institute of Physics, Chinese Academy of Sciences, Beijing, 100190, China. "E-mail: yshu@iphy.ac.cn

${ }^{\mathrm{d}}$ Innovation Academy for Green Manufacture, Chinese Academy of Sciences, Beijing 100190, China 


\section{Experiment Section}

\section{Material Synthesis}

The $\mathrm{Na}_{4} \mathrm{VMn}\left(\mathrm{PO}_{4}\right)_{3} / \mathrm{C}$ cathodes were prepared via a sol-gel method followed by a high temperature calcination process under $\mathrm{Ar}$ atmosphere. In detail, stoichiometric amounts sodium acetate $\left(\mathrm{C}_{2} \mathrm{H}_{3} \mathrm{NaO}_{2}\right)$, manganese acetate $\left(\mathrm{C}_{4} \mathrm{H}_{14} \mathrm{MnO}_{8}\right)$, vanadium acetylacetonate $\left(\mathrm{C}_{15} \mathrm{H}_{21} \mathrm{O}_{6} \mathrm{~V}\right)$, phosphoric acid $\left(\mathrm{H}_{3} \mathrm{PO}_{4}\right)$ and appropriate amount anhydrous citric acid $\left(\mathrm{C}_{6} \mathrm{H}_{8} \mathrm{O}_{7}\right)$ were added into 100 $\mathrm{mL}$ ethanol solution to obtain 0.01 mole precursor. The mixed solution was then transferred into a constant temperature water bath $\left(80^{\circ} \mathrm{C}\right)$ under a magnetic stirring of $\sim 300 \mathrm{r} / \mathrm{min}$ to evaporate the solvent. The obtained green sol/gel was dried at $100^{\circ} \mathrm{C}$ in a vacuum oven for overnight. Finally, the precursor powder was further subjected to a high temperature calcination $\left(650^{\circ} \mathrm{C}\right)$ for $5 \mathrm{~h}$ to the final cathode materials. Other cathode materials involved in this work are synthesized by a similar approach. Aluminum isopropoxide $\left(\mathrm{C}_{9} \mathrm{H}_{21} \mathrm{AlO}_{3}\right)$, tetrabutyl titanate $\left(\mathrm{C}_{16} \mathrm{H}_{36} \mathrm{O}_{4} \mathrm{Ti}\right)$ and magnesium acetate $\left(\mathrm{C}_{4} \mathrm{H}_{14} \mathrm{MgO}_{8}\right)$ are employed as aluminum, titanium and magnesium dopants respectively. All the regents with analytical purity were purchased from Shanghai Aladdin Biochemical Technology Co., Ltd.

\section{Material Characteristics}

The crystal structure of samples was characterized by X-ray diffractometer (XRD, Cu Ka, Smartlab-9). The XRD refinement was performed by the GSASS software. The X-ray photoelectron spectroscopy (XPS, AI, KaESCALAB250Xi) 
was employed to determine the elements valence and structure information of samples and electrodes. The inductively coupled plasma-optical emission spectroscopy (ICP, 7000DV) was carried out to confirm elements composition of samples. The samples were firstly calcinated at $500{ }^{\circ} \mathrm{C}$ for $3 \mathrm{~h}$ under air atmosphere to remove the carbon layer. The obtained dark yellow powder was then dissolved in the diluted acid solution to conduct the ICP measurements. Carbon content of samples was analyzed by thermogravimetric analyzer (TGA, DTA6300). Brunauer-Emmett-Teller (BET) specific surface area and pore size distribution of samples were measured by nitrogen adsorption-desorption curves. The detailed structure features of samples were further characterized by Raman spectra (Laser GS6000) and Fourier-transform infrared spectroscopy (FTIR, T27). The surface morphology and energy-dispersive spectroscope (EDS) were observed by the scanning electron microscope (SEM, EM30 plus, COXEM). The lattice springers and fine microstructure of samples were detected by the high-resolution transmission electron microscope (HRTEM, JEM-1400 Flash). The total reflection X-ray fluorescence (TXRF, Mo Ka, S4 Tstar 400) was carried out to analyze the dissolution of Mn ions from cycled electrodes. For the ex-situ XRF experiment, the electrodes (the loading of active materials is same) together with the glass fiber separator and spring sheet etc. were fully soaked in the dimethyl carbonate solution under a glove box. In addition, in the ex-situ XPS testing, the electrodes were disassembled and directly sealed to avoid exposure to air. And, the in situ XRD measurements 
during electrochemical reaction process were performed on X-ray diffractometer equipped with a planar detector employing a special cell configuration.

\section{Electrochemical measurements}

To fabricate cathode electrodes, the active materials, Ketjenblack (KB) and poly(tetrafluoroethylene) (PTFE) binder at a mass ratio of 7:2:1 were strictly ground and mixed, followed by a sufficient rolling procedure until formation of an evenly-mixed electrode thin film. The as-obtained electrode film is then cut into $6 \times 6 \mathrm{~mm}$ square electrodes and ensure that the loading content of active substance is above $5.5 \mathrm{mg} \mathrm{cm}^{-2}$. Commercial hard carbon $(\mathrm{HiNa})$ electrode is consisted of hard carbon materials, acetylene black and poly(vinylidenefluoride) (PVDF) at a mass ratio of 9:0.5:0.5. For half-cell, the 2032 coin-type cells were assembled in the glove box full of $\operatorname{Ar}\left(\mathrm{H}_{2} \mathrm{O}\right.$ and $\mathrm{O}_{2}$ concentration less than $0.01 \mathrm{ppm})$, employing Na metal as counter, glass fiber as separator and $1 \mathrm{M} \mathrm{NaClO}$ in propylene carbonate (PC) with $2 \%$ fluoroethylene carbonate (FEC) additive as electrolyte. The galvanostatic charge/discharge measurements under various current densities between 2.5 to $3.8 \mathrm{~V}$ were performed on a Land battery testing system. In the rate performance measurements, the current density is the same in charge and discharge process in the case of low rates $(0.2-10 \mathrm{C})$. However, at the higher rate testing, the charge current density is maintained at $10 \mathrm{C}$, and the discharge current densities are in turn to set as 20,30 and 40 C. Specially, the nominal 
capacity of $1 \mathrm{C}$ is designated as $110 \mathrm{~mA} \mathrm{~g}^{-1}$. The capacities presented in this work were calculated based on the pure active materials (which have been deducted the coating carbon weight). In terms of fabrication of full cells, all procedures are the same as half-cell assembly except for the utilization of the hard carbon electrode as counter. The voltage window for the full cell is within 1.5-3.8 V. All of the electrochemical impedance spectroscopy (EIS) data were collected via an electrochemical workstation ( $Z$ ahner, IM6). For the GITT measurements, all of the electrodes are galvanostatically charged or discharged for $10 \mathrm{~min}$ followed by a rest of 40 min to obtain a nearly steady state. The relevant parameters of $\mathrm{T}, \Delta E_{s}, \Delta E_{T}$, and etc. are schematically presented in the Figure S9. Owing to the linear relationship between cell potential and $T^{0.5}$, the calculation of $D_{\mathrm{Na}^{+}}$could be simplified as the following the equation: $D_{N a^{+}}=4 / \pi T\left(m_{B} V_{m} / M_{B} S\right)^{2}\left(\Delta E_{S} / \Delta E_{T}\right)^{2} \quad\left(T<<R / D_{N a^{+}}\right)$ where $m_{B}, M_{B}, V_{m}$, $S$ represent mass, molecular weight, molar volume and surface area of the cathode material respectively. 


\section{Theoretical Calculation Section}

\section{Calculation method}

First-principles calculations were conducted to estimate the energies of the given materials based on the spin-polarized generalized gradient approximation (GGA) using DFT. We used a plane-wave basis set and the projector-augmented wave (PAW) method implemented in the Vienna ab initio simulation package (VASP) $)_{[\text {ref-VASP]. }}$ PAW potentials have shown good predictive capability in cathode materials for $\mathrm{Na}$ rechargeable batteries, and the Hubbard parameter was added to correct for the strong-correlation of transition metal $\mathrm{Mn}$ and $\mathrm{V}$. $\mathrm{U}_{\text {eff }}$ values for $\mathrm{Mn}$ of $3.90 \mathrm{eV}$ and for $\mathrm{V}$ of $3.25 \mathrm{eV}$ were selected, which were previously used in studies on $\mathrm{Na}_{4} \mathrm{VMn}\left(\mathrm{PO}_{4}\right)_{3}$. A plane-wave basis with an energy cutoff of $520 \mathrm{eV}$ was used. The Brillouin zone integrations were conducted by employing $\Gamma 1 \times 1 \times 1$ for geometric optimization. All the structures were optimized until the force in the unit cell converged to within 0.02 $\mathrm{eV} \AA-1$.

[ref_VASP] Kresse, G.; Furthmuller, J. Efficient iterative schemes for ab initio total-energy calculations using a plane-wave basis set. Phys. Rev. B: Condens. Matter Mater. Phys. 1996, 54 (16), 11169-11186. 


\section{Figure and Graph Section}

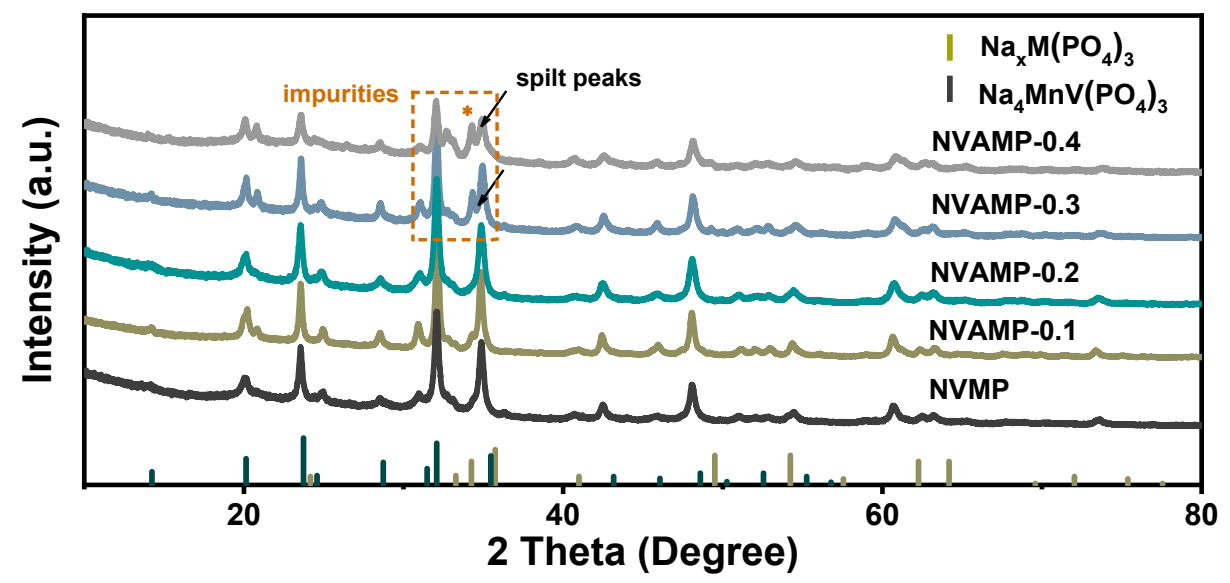

Figure S1. The $\mathrm{XRD}$ patterns of $\mathrm{Na}_{4} \mathrm{~V}_{1-\mathrm{x}} \mathrm{Al} \mathrm{I}_{\mathrm{X}} \mathrm{Mn}\left(\mathrm{PO}_{4}\right)_{3} \quad(0 \leq \mathrm{x} \leq 0.4)$ samples synthesized at $650{ }^{\circ} \mathrm{C}$. 

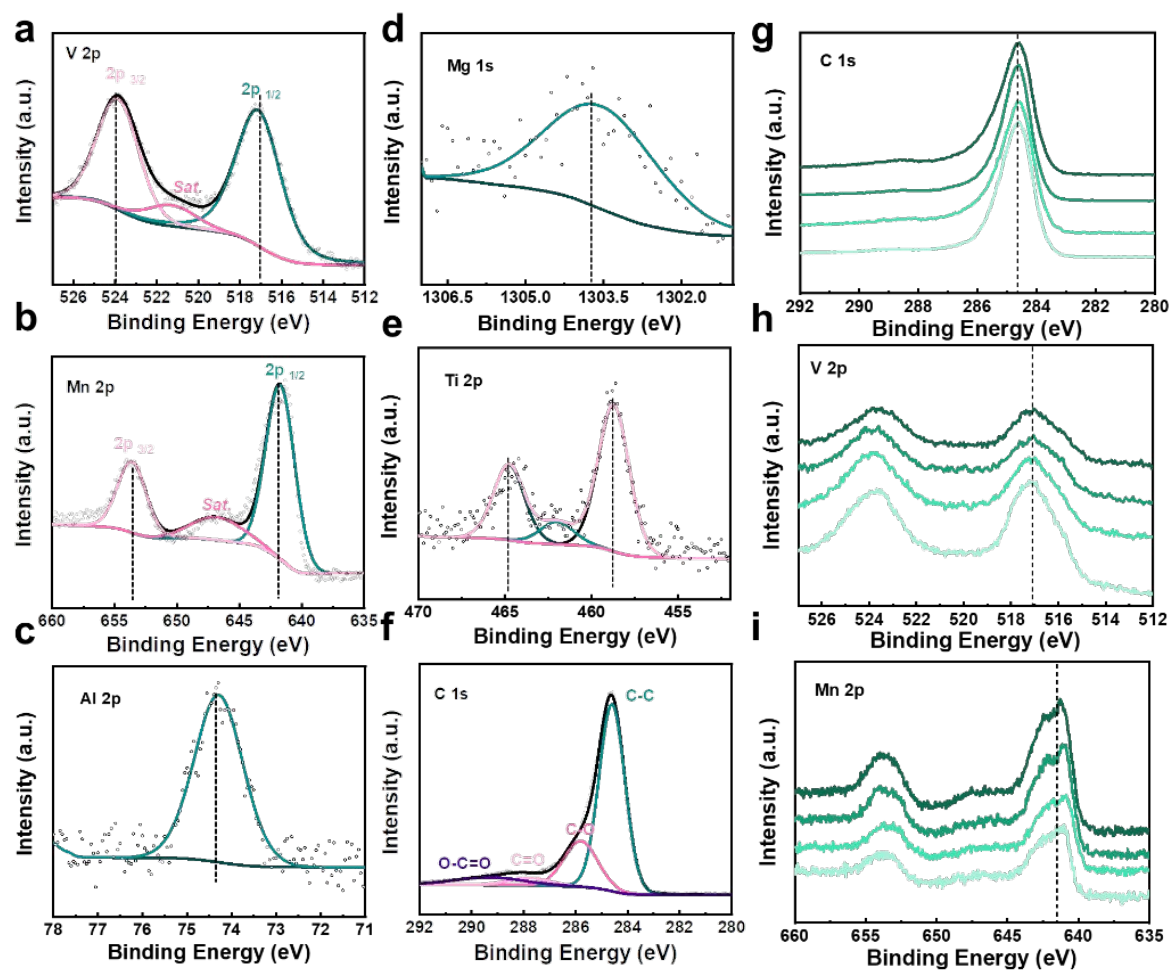

Figure S2. The XPS spectra of $\vee 2 p(a)$ and Mn $2 p(b)$ in the NVAMP cathode.

The fitted core-level spectra of Al $2 p$ (c) Mg $1 \mathrm{~s}(\mathrm{~d})$ and Ti $2 p(e)$ for NVAMP, NVMMP and NVTMP cathodes, respectively. The fitted core-level C 1s (f) in the NVAMP cathode. The high-revolution XPS spectra comparation of C $1 \mathrm{~s}(\mathrm{~g})$, V $2 \mathrm{p}(\mathrm{h})$ and Mn $2 \mathrm{p}$ (i) between the NVMP, NVAMP, NVMMP and NVTMP cathodes. 


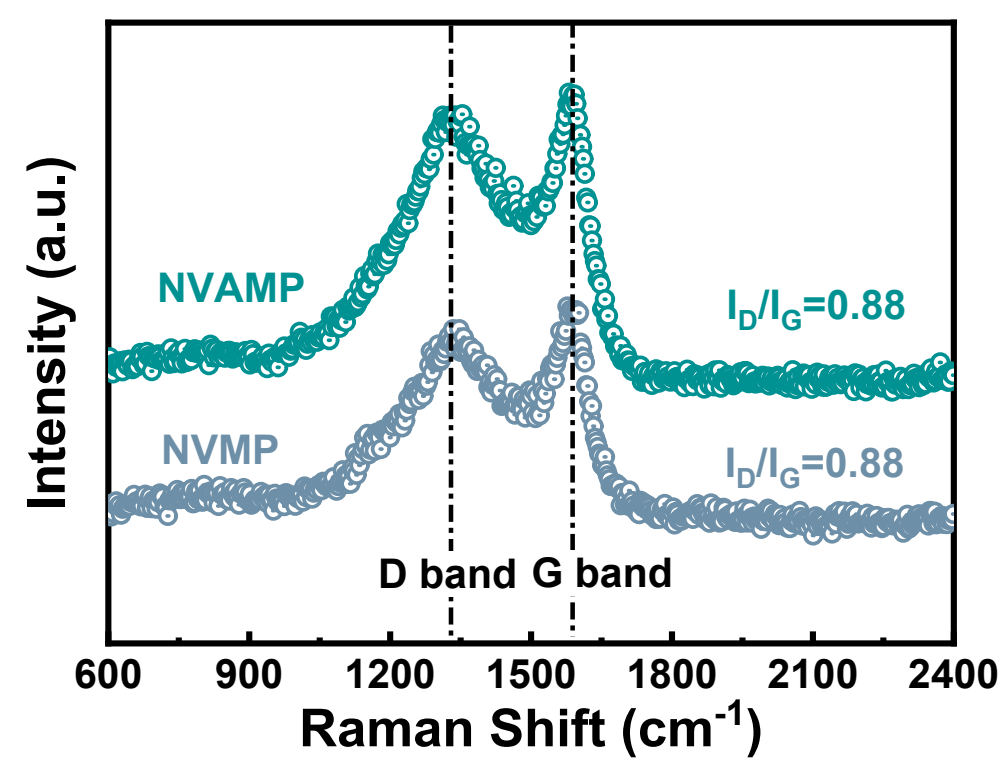

Figure S3. The Raman spectrum comparison of NVAMP and NVMP cathodes. 

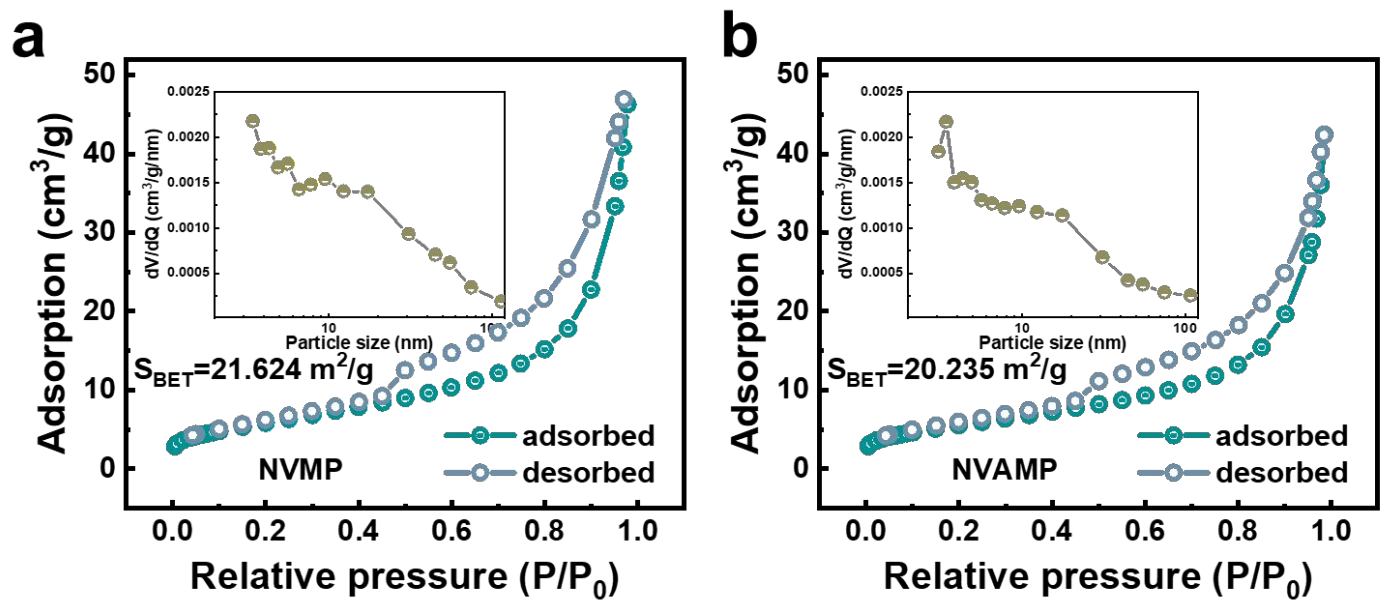

Figure S4. The nitrogen adsorption-desorption curves with inserted pore-size distribution of NVMP (a) and NVAMP (b) cathodes. 


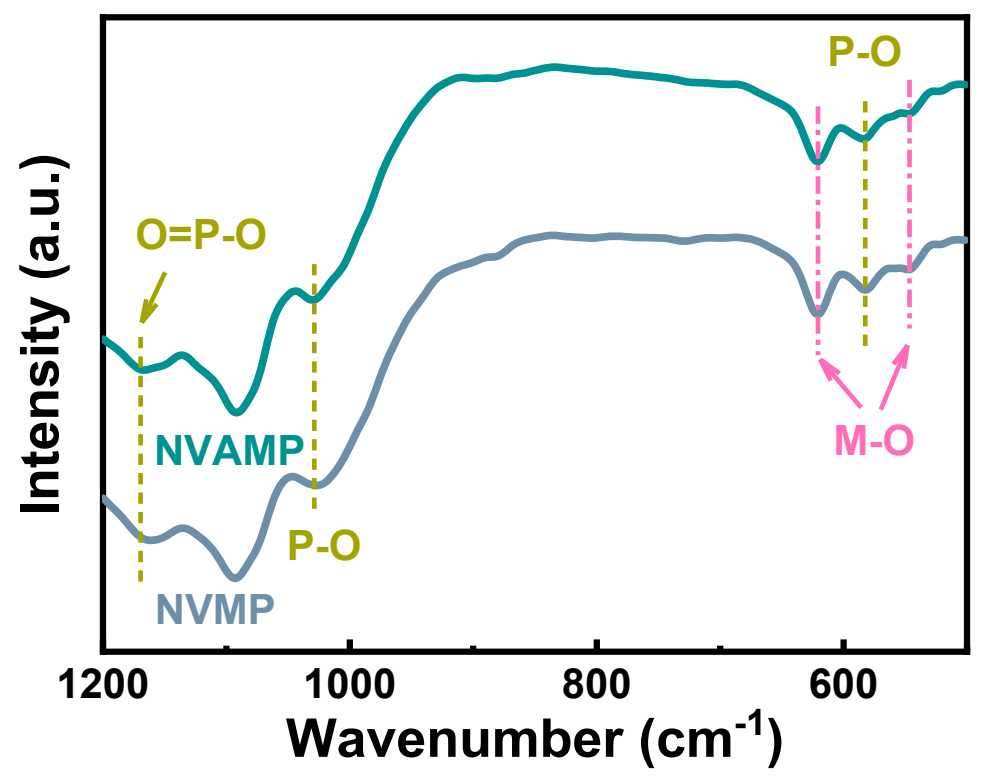

Figure S5. The FTIR spectra of NVMP and NVAMP cathodes. 

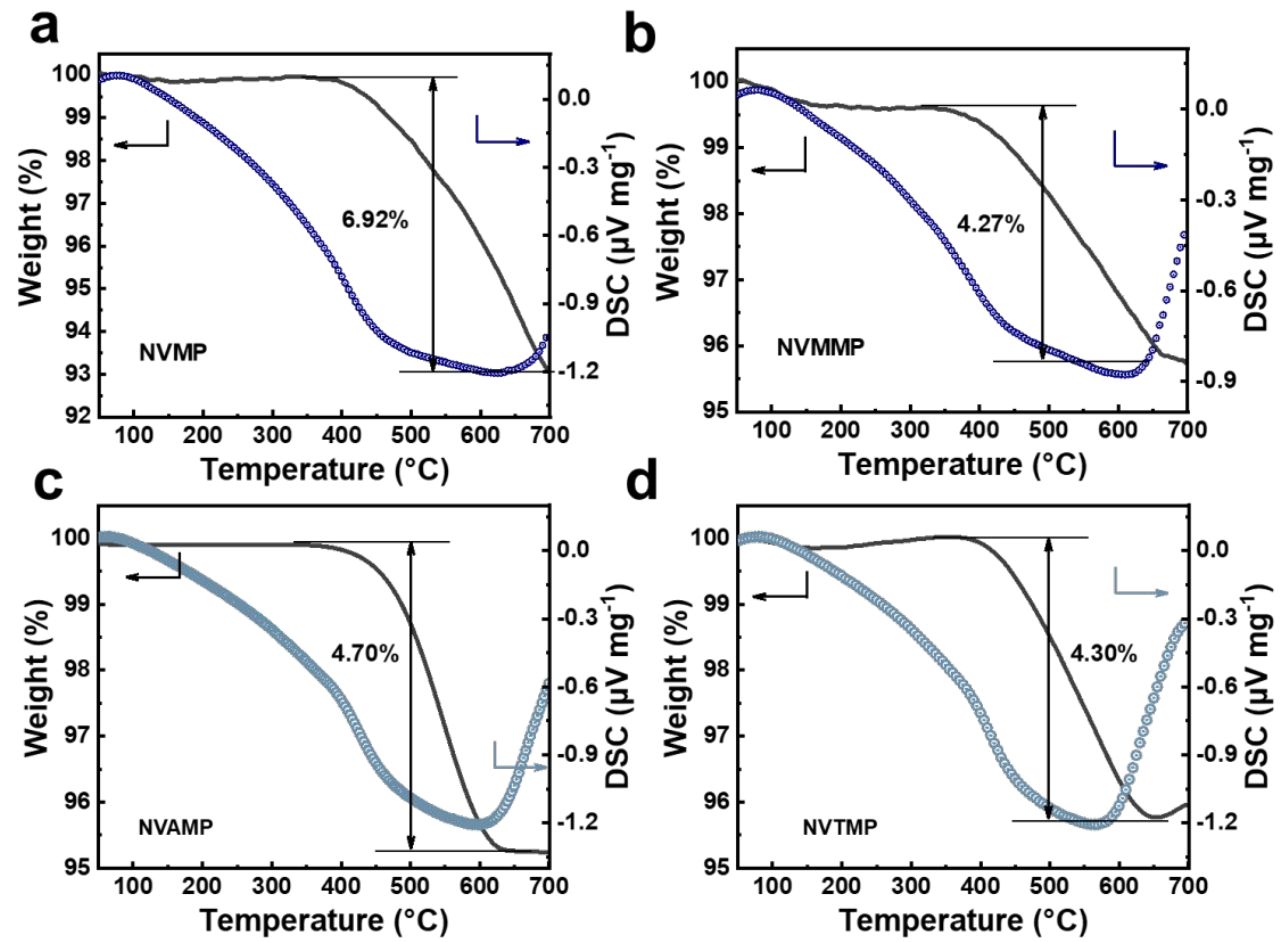

Figure S6. The TG curves with DSC profiles of NVMP (a), NVMMP (b), NVAMP (c) and NVTMP (d) cathodes. 

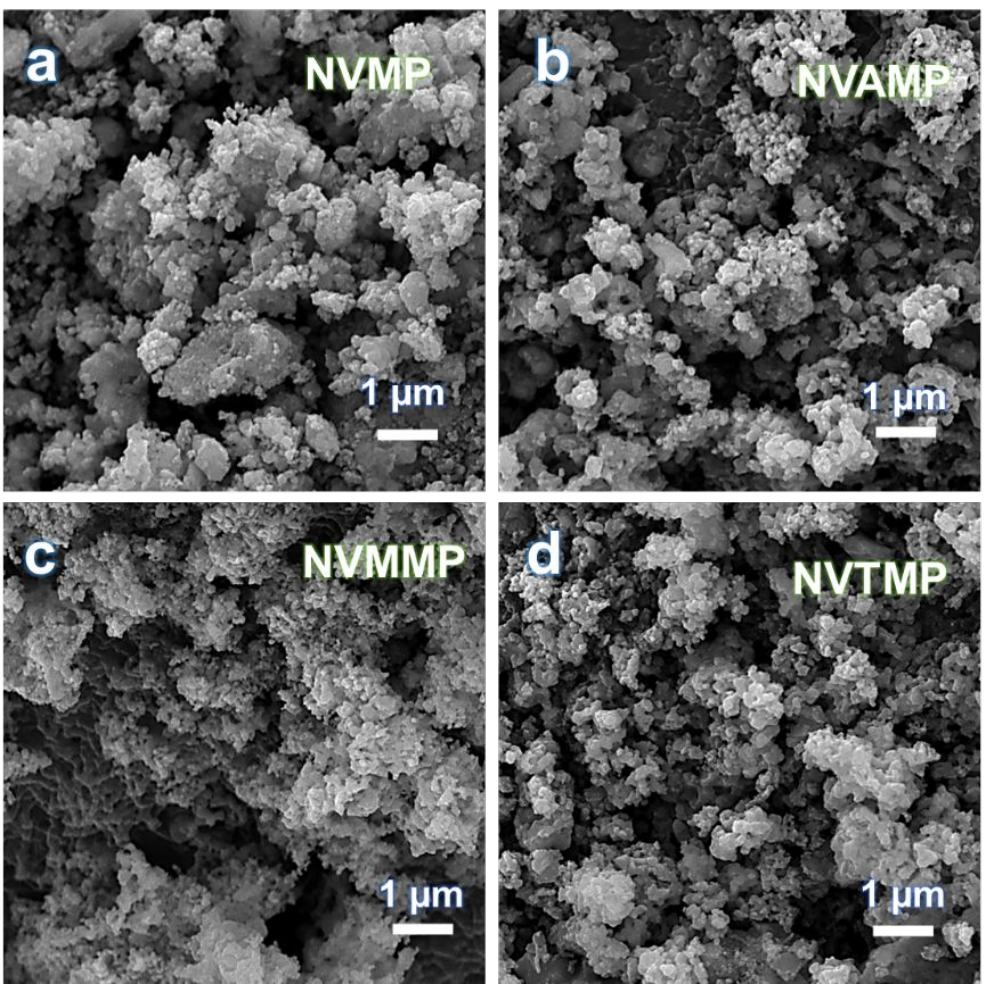

Figure S7. The SEM images of NVMP (a), NVAMP (b), NVMMP (c) and NVTMP (d) cathodes. 

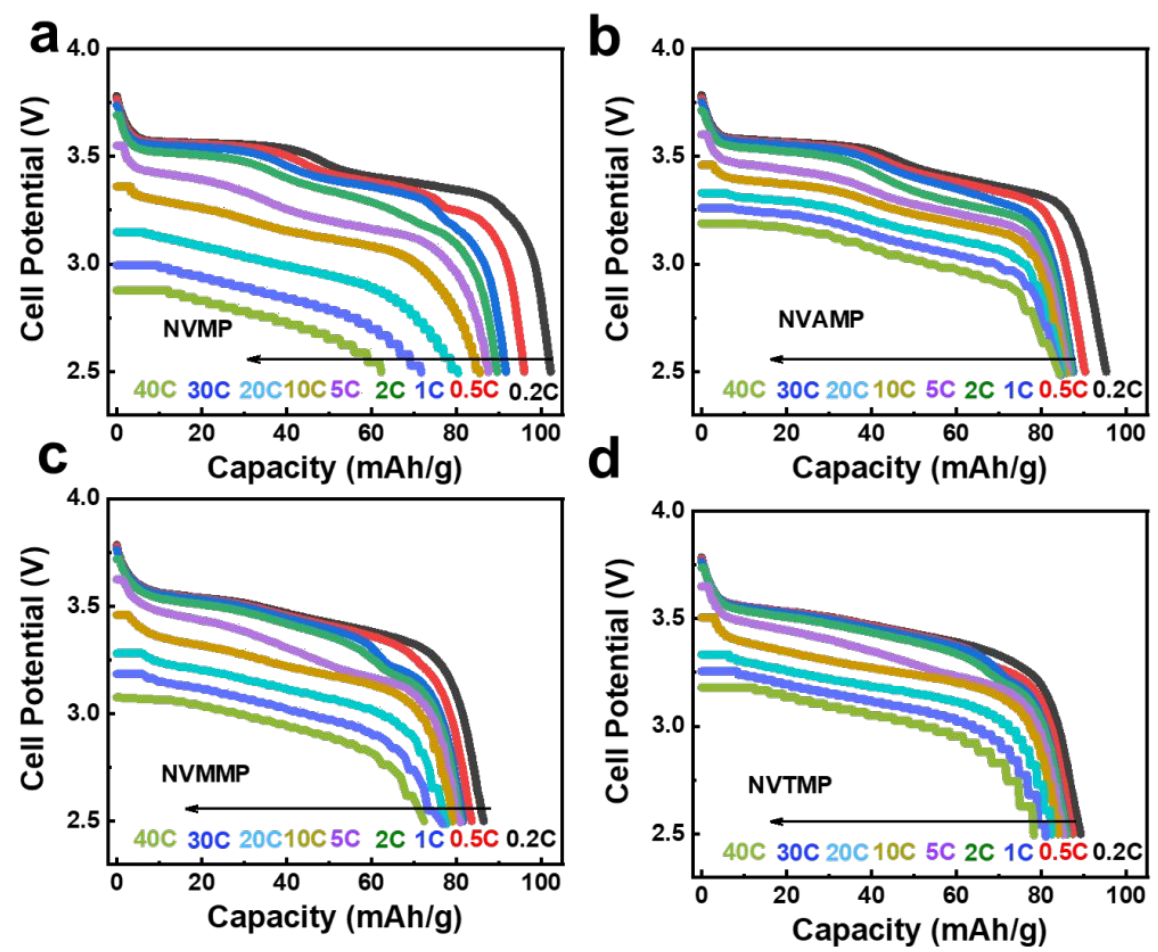

Figure S8. The discharge curves at various current densities for NVMP (a), NVAMP (b), NVMMP (c) and NVTMP (d) electrodes. 

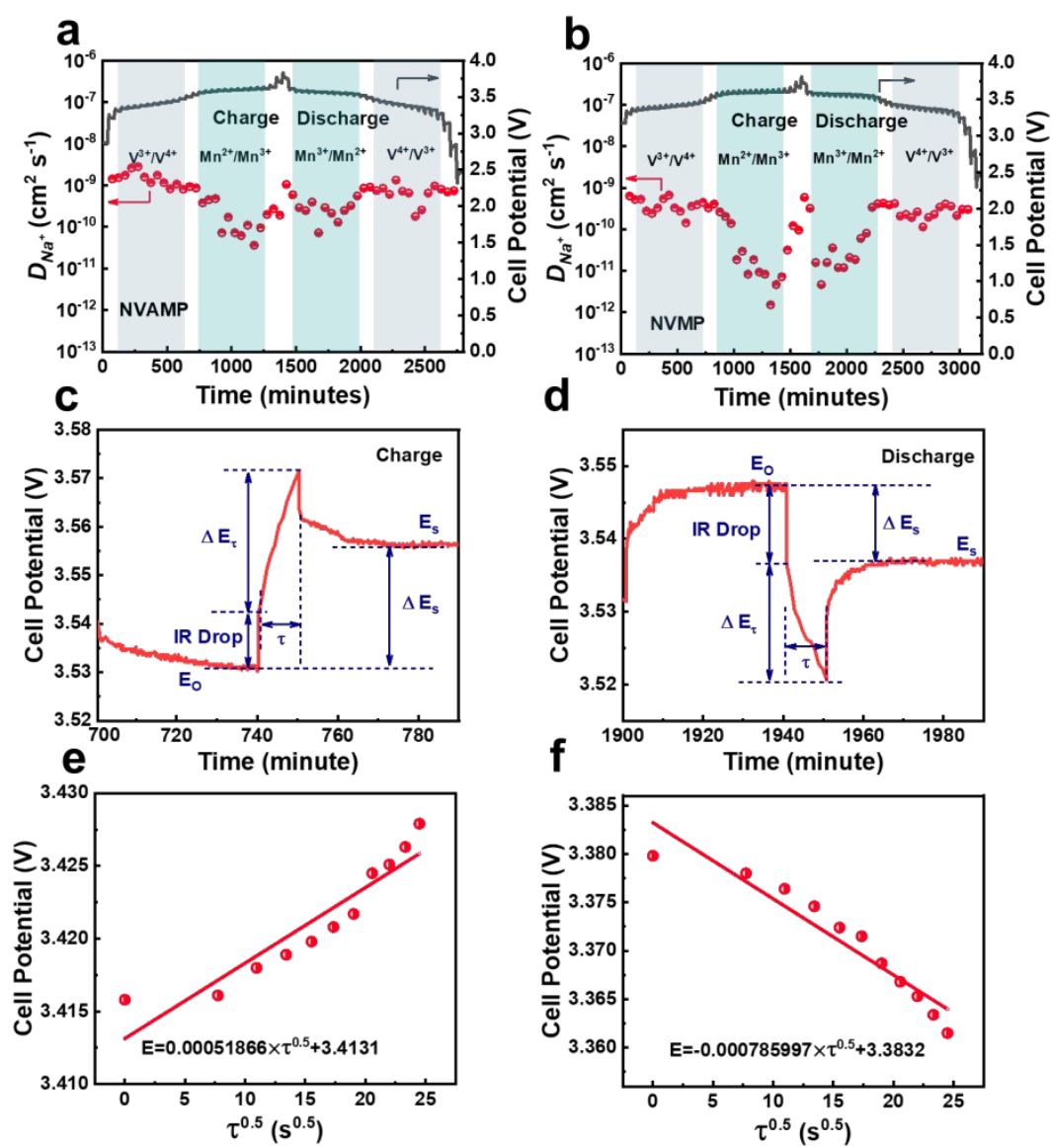

Figure S9. The GITT measurements curves of NVAMP (a) and NVMP (b) electrodes and $D_{\mathrm{Na}}{ }^{+} v$ s. cell potential profiles during charge/discharge process. The typical profiles of the single-step GITT experiment with remarked parameters during charge (c) or discharge (d) process. The corresponding fitted linear curve as a function of cell potential vs. $T^{0.5}$ for during charge (e) and discharge (f) process. 


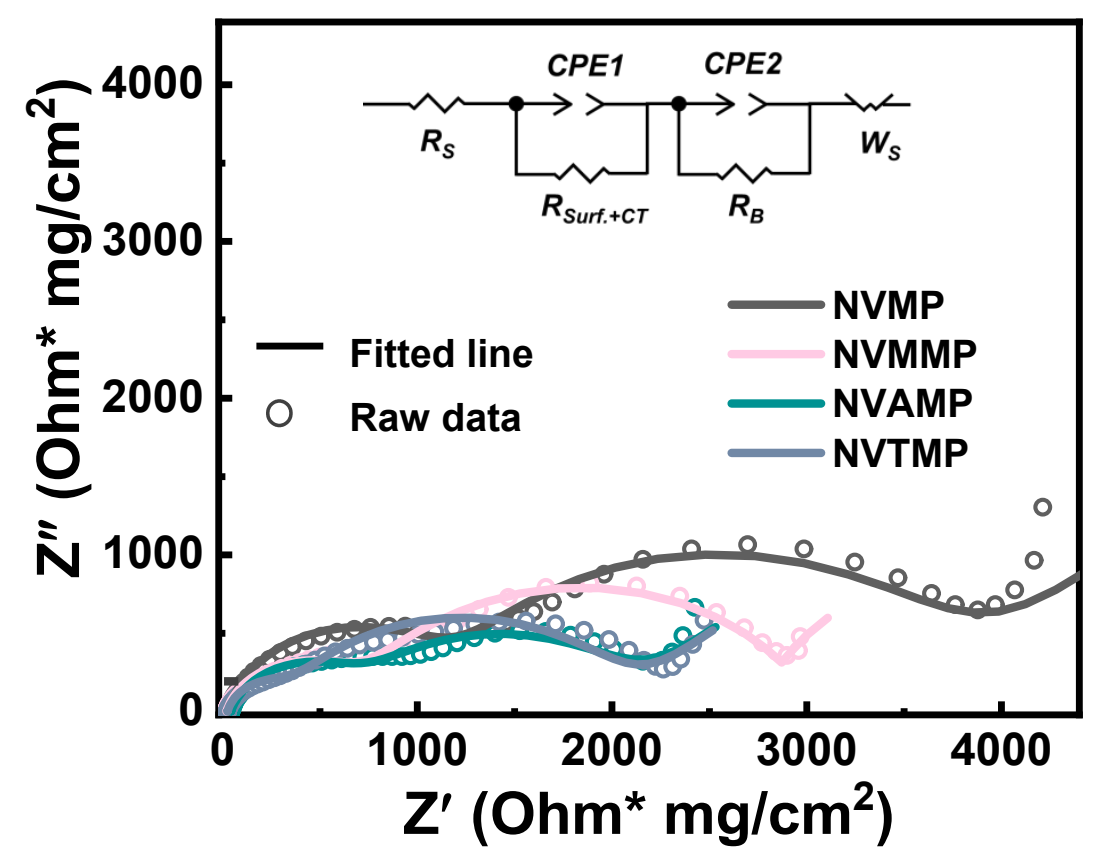

Figure S10. The EIS Nyquist plots including raw data and fitted lines for several fresh electrodes. The resistance values were normalized by $\mathrm{Ohm}^{*} \mathrm{mg} / \mathrm{cm}^{2}$, and the loading of the electrodes is about $5.5 \mathrm{mg} / \mathrm{cm}^{2}$. The inset is the equivalent electrical circuit simulated by Z-view software. 

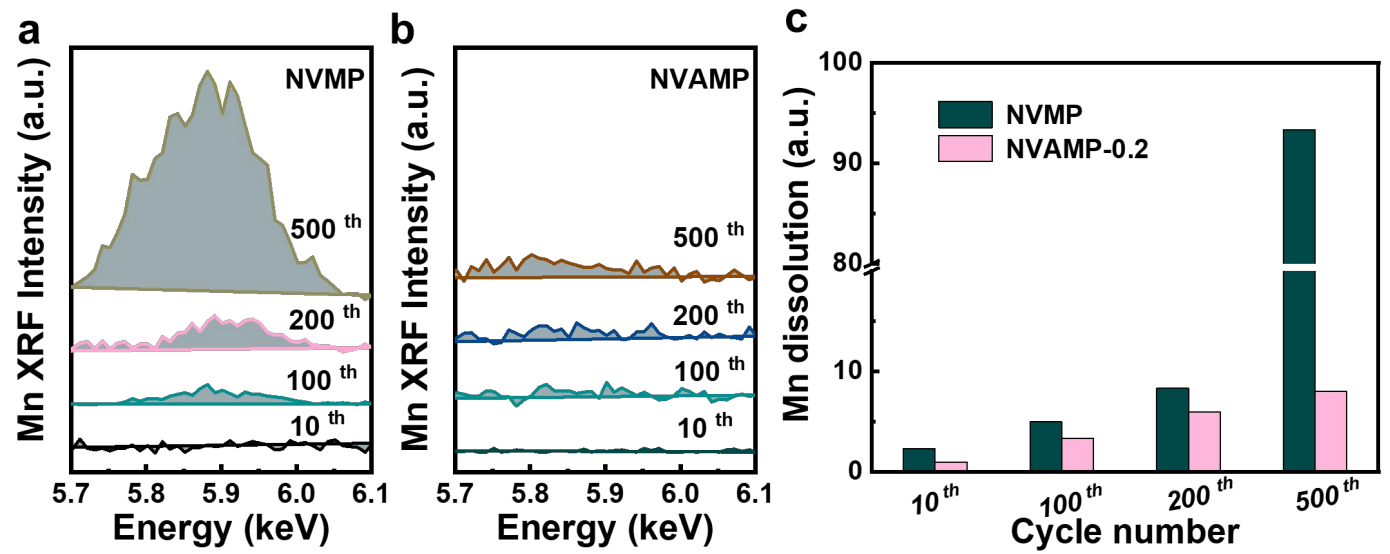

Figure S11. The Mn XRF of NVMP (a) and NVAMP (b) electrodes after different cycles at 5 C. (c) The semiquantitative content comparison of dissolved Mn ions based on the integral area of the XRF peaks. The Mn dissolution content of the cycled NVAMP electrode for 10 cycles was defined as "1" unit. 

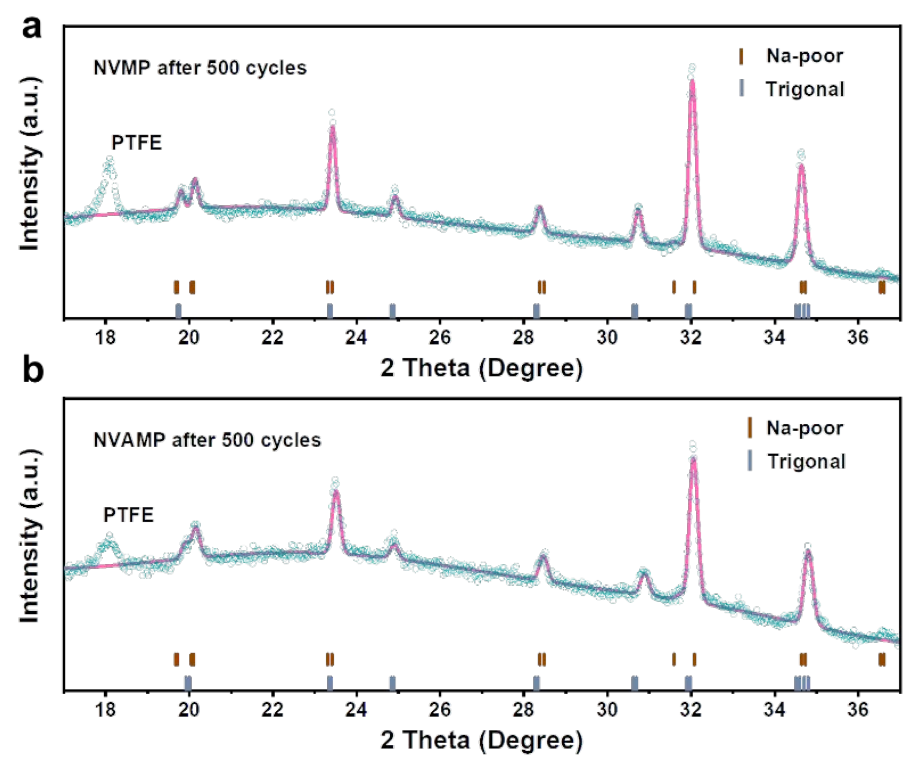

Figure S12. The refined XRD patterns of NVMP (a) and NVAMP (b) electrodes after cycling 500 cycles at $5 \mathrm{C}$. 

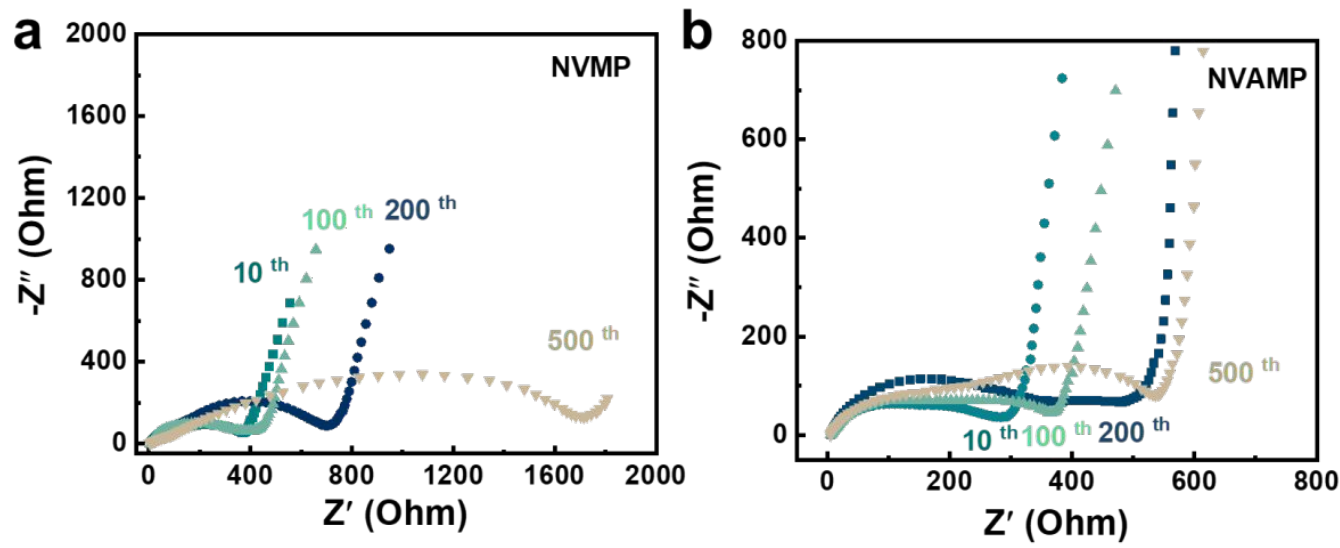

Figure S13. The EIS Nyquist plots of the NVMP and NVAMP electrodes after cycling different numbers of cycles. 


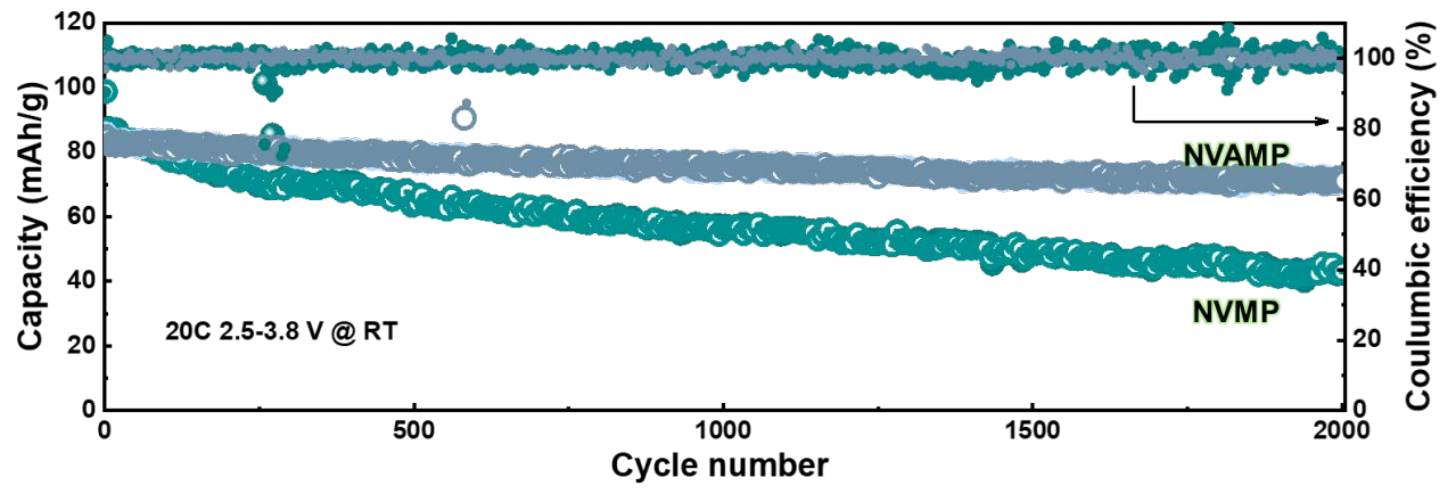

Figure S14. The cycling performance comparison between NVMP and NVAMP electrodes cycled at $20 \mathrm{C}$. 


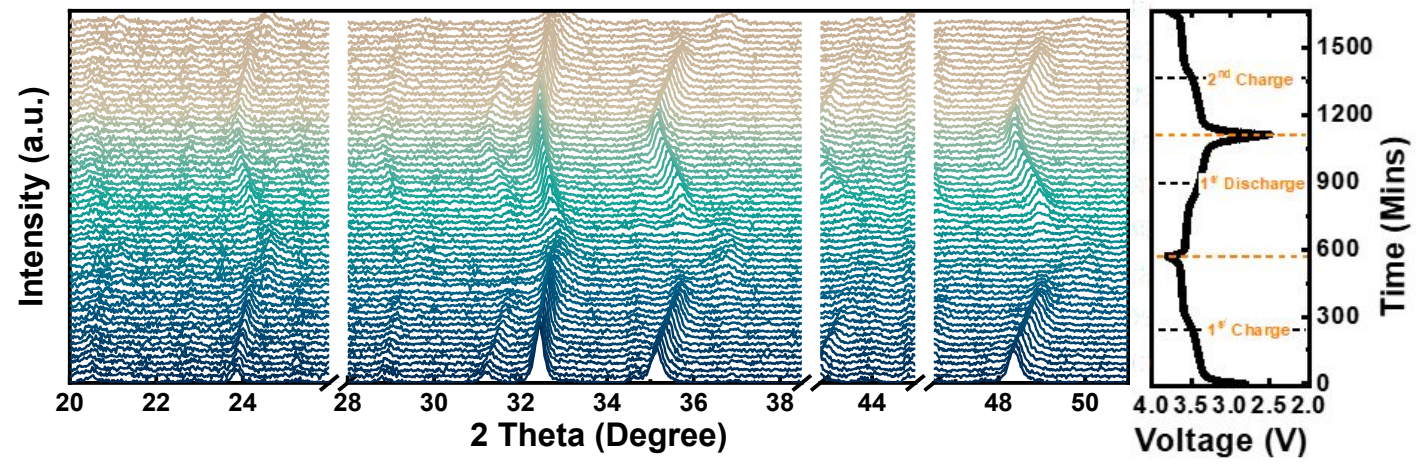

Figure S15. The in-situ XRD patterns of NVAMP electrode collected at the selected angle range for the first charge/discharge and the second charge process. 


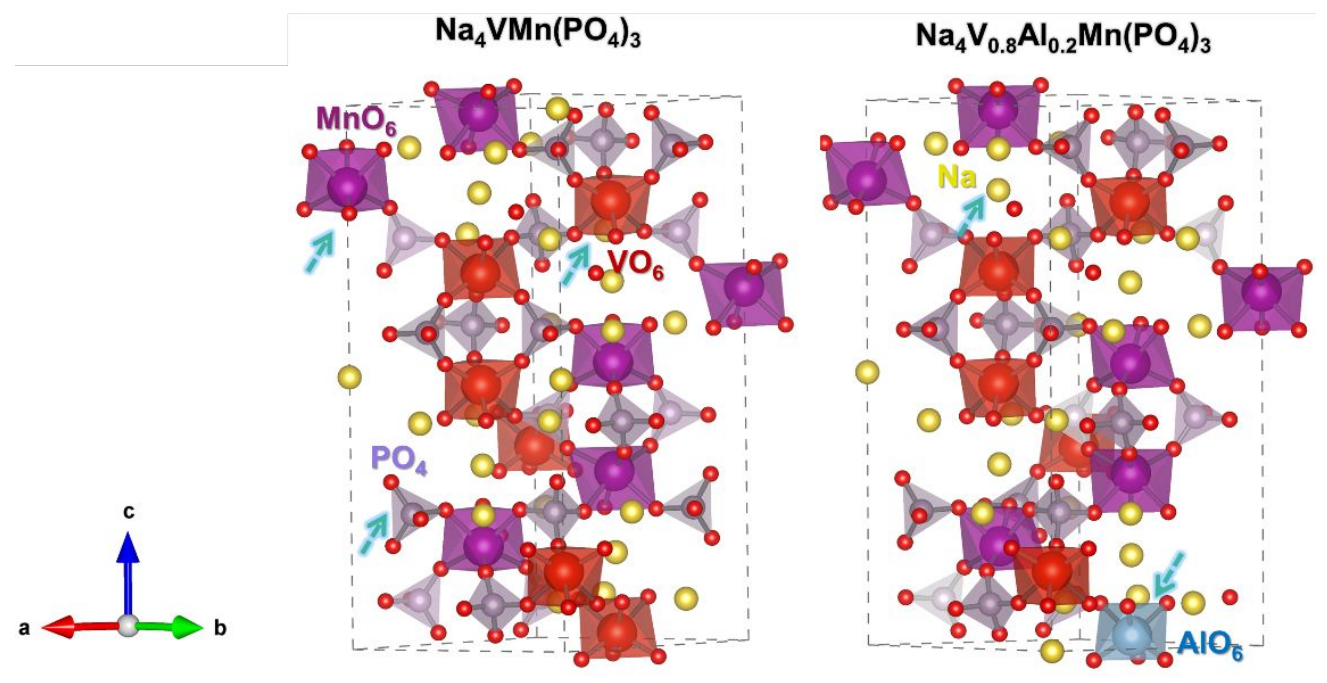

Figure S16. The schematic illustration of DFT models of NVMP and NVAMP cathodes. The calculation models of NVMP and NVAMP are $\mathrm{Na}_{24} \mathrm{~V}_{6} \mathrm{Mn}_{6} \mathrm{P}_{18} \mathrm{O}_{72}$ and $\mathrm{Na}_{24} \mathrm{~V}_{5} \mathrm{AlMn}_{6} \mathrm{P}_{18} \mathrm{O}_{72}$. 

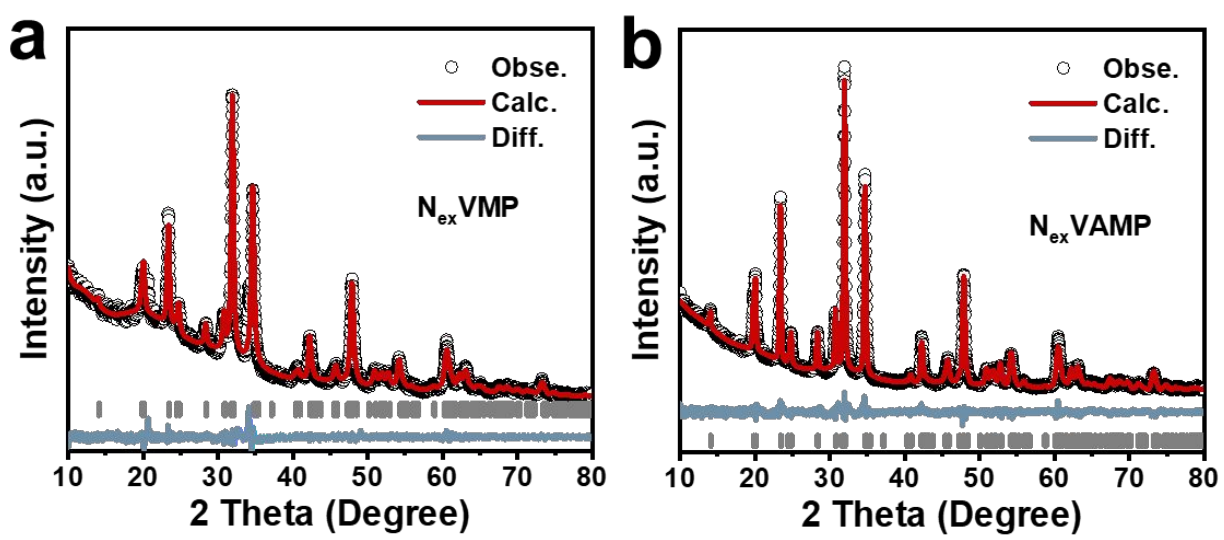

Figure S17. The XRD Rietveld refinements of $\mathrm{N}_{\mathrm{ex}} \mathrm{VMP}$ and $\mathrm{N}_{\mathrm{ex}} \mathrm{VAMP}$ cathodes.

The relatively small error factor of $R_{p}\left(4.05 \%\right.$ for $\mathrm{N}_{\mathrm{ex}} \mathrm{VMP}$ and $3.93 \%$ for $\left.\mathrm{N}_{\mathrm{ex}} \mathrm{VAMP}\right), R_{\text {wp }}\left(5.11 \%\right.$ for $\mathrm{N}_{\mathrm{ex}} \mathrm{VMP}$ and $4.76 \%$ for $\left.\mathrm{N}_{\mathrm{ex}} \mathrm{VAMP}\right)$ and variance $X^{2}$ (1.99 for $\mathrm{N}_{\mathrm{ex}} \mathrm{VMP}$ and 1.54 for $\mathrm{N}_{\mathrm{ex}} \mathrm{VAMP}$ ) indicate the refined results are reliable. 

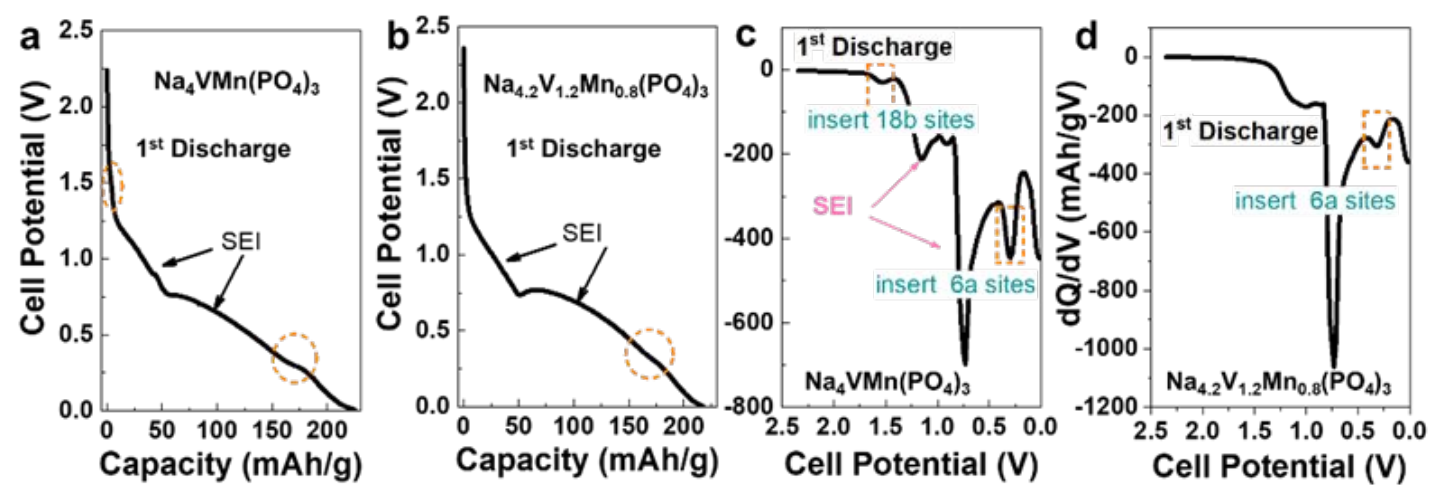

Figure S18. The sodiation profiles of $\mathrm{Na}_{4} \mathrm{VMn}\left(\mathrm{PO}_{4}\right)_{3}$ (a) and $\mathrm{Na}$ excessive

$\mathrm{Na}_{4.2} \mathrm{~V}_{0.8} \mathrm{Mn}_{1.2}\left(\mathrm{PO}_{4}\right)_{3}$ cathodes (b) at $0.2 \mathrm{C}$. The corresponding $\mathrm{dQ} / \mathrm{dV}$ curves of $\mathrm{Na}_{4} \mathrm{VMn}\left(\mathrm{PO}_{4}\right)_{3}$ (c) and $\mathrm{Na}_{4.2} \mathrm{~V}_{0.8} \mathrm{Mn}_{1.2}\left(\mathrm{PO}_{4}\right)_{3}$ (c) cathodes. 


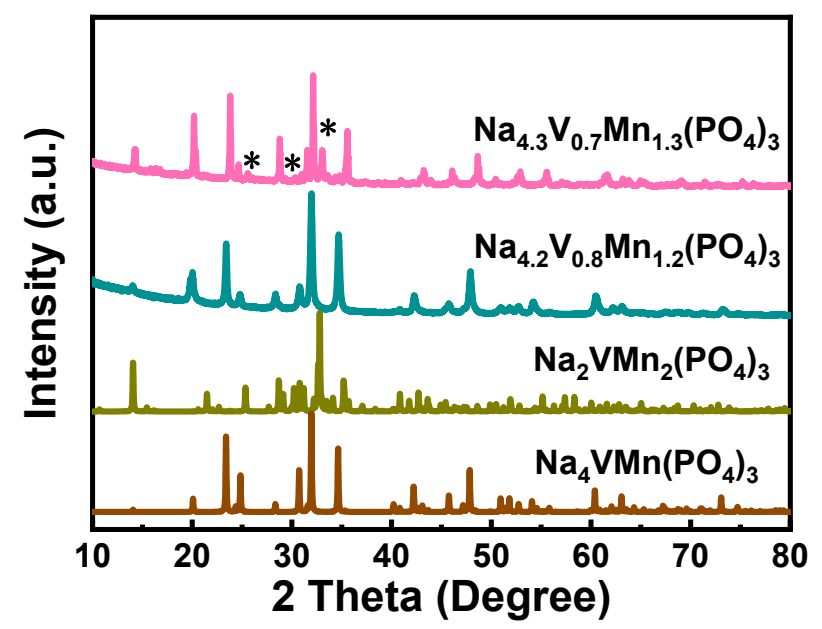

Figure S19. The XRD patterns of $\mathrm{Na}_{4.3} \mathrm{~V}_{0.7} \mathrm{Mn}_{1.3}\left(\mathrm{PO}_{4}\right)_{3}$ cathode. The high $\mathrm{Mn} / \mathrm{V}$ ratios have led to the generation of alluaudite-type $\mathrm{Na}_{2} \mathrm{Mn}_{2} \mathrm{~V}\left(\mathrm{PO}_{4}\right)_{3}$ impurities. However, note that the $\mathrm{Na}_{4.2} \mathrm{~V}_{0.8} \mathrm{Mn}_{1.2}\left(\mathrm{PO}_{4}\right)_{3}$ shows high consistency with the standard $\mathrm{Na}_{4} \mathrm{VMn}\left(\mathrm{PO}_{4}\right)_{3} \mathrm{XRD}$ patterns. 

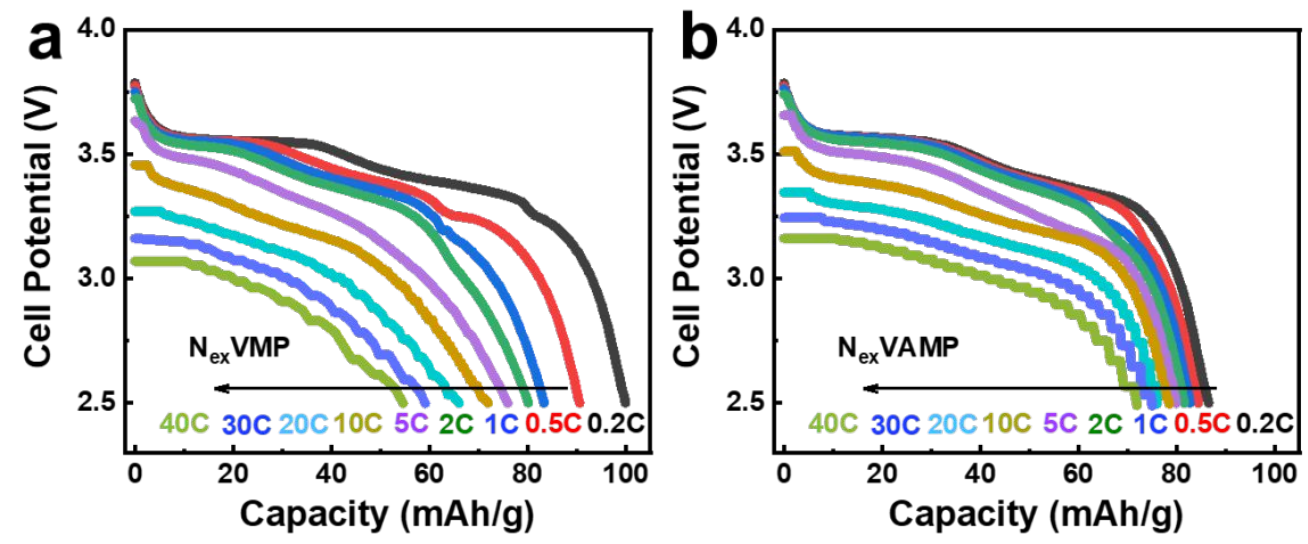

Figure S20. The discharge curves of $\mathrm{N}_{\mathrm{ex}} \mathrm{VMP}$ and $\mathrm{N}_{\mathrm{ex}}$ VAMP electrodes at different current densities $(0.2-40 \mathrm{C})$. It could be observed that $\mathrm{N}_{\mathrm{ex}} \mathrm{VAMP}$ electrode shows better rate capability. 

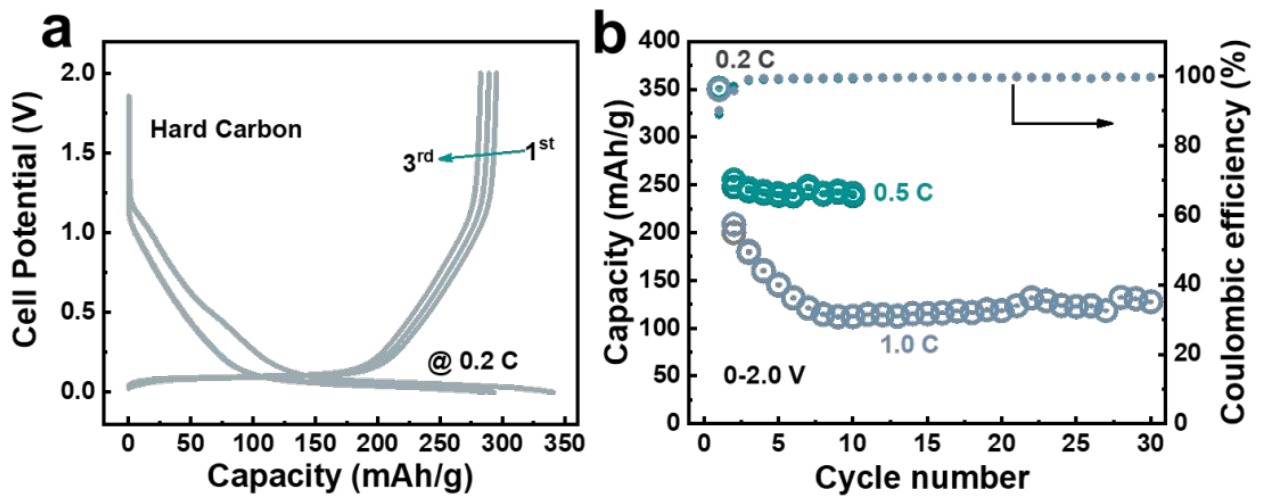

Figure S21. (a) The initial three discharge/charge curves of the hard carbon half cells. Specially, $1 \mathrm{C}$ was defined as $330 \mathrm{~mA} \mathrm{~g}^{-1}$. (b) The evaluation of cycling performance $(0.5 \mathrm{C}$ and $1 \mathrm{C})$ for the hard carbon anode. The coulomb efficiency was defined as the value of $\mathrm{Cap}_{\text {.charge }} / \mathrm{Cap}_{\text {.discharge. }}$. It can be found that the hard carbon can deliver the initial capacities of $\sim 250$ and $\sim 200 \mathrm{~mA} \mathrm{~h} \mathrm{~g}^{-}$ ${ }^{1}$ at $0.5 \mathrm{C}$ and $1 \mathrm{C}$, respectively. However, a capacity retention of only $63 \%$ could be obtained after 30 cycles at $1 \mathrm{C}$. 

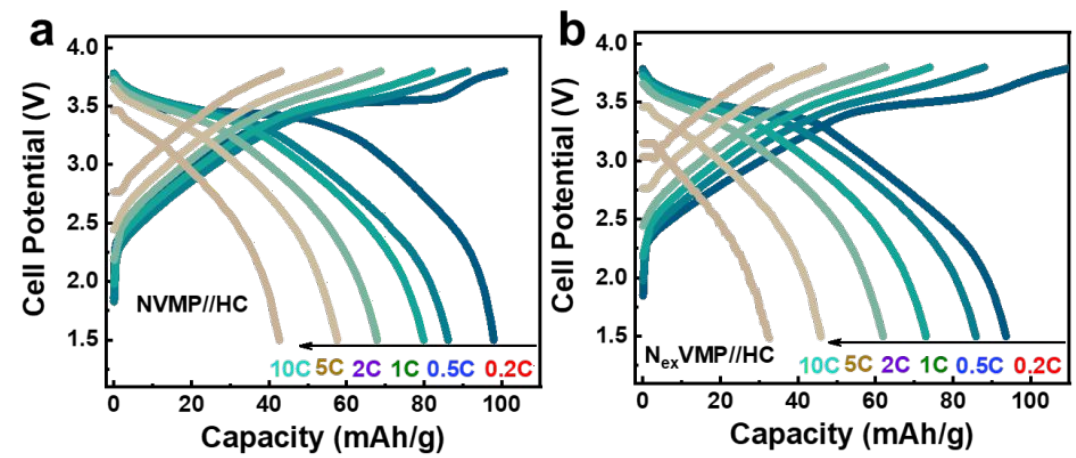

Figure S22. The charge/ discharge curves of NVMP (a) and $\mathrm{N}_{\mathrm{ex}} \mathrm{VMP}(\mathrm{b})$ cointype full cells at different current densities (0.2-10 C). 


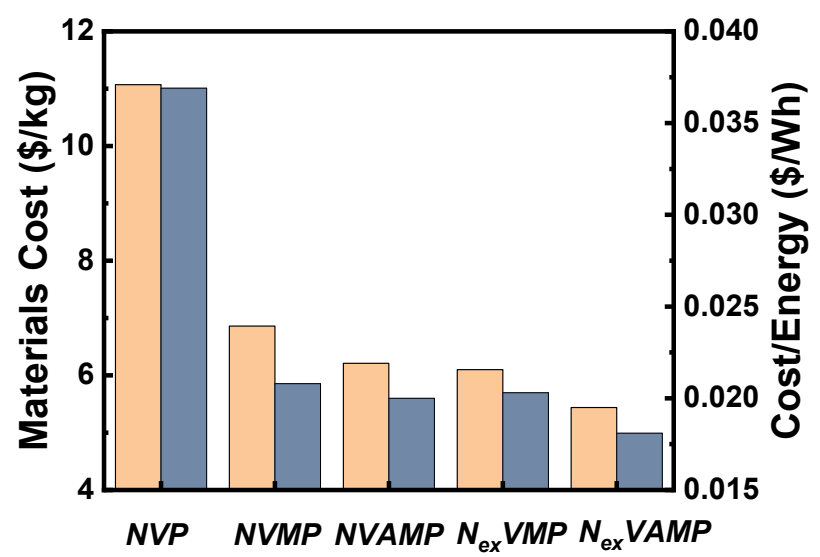

Figure S23. The Raw materials cost and corresponding cost/performance ratio of several cathodes.

These raw materials adopted the easily-prepared metal oxides or carbonates etc. from the perspective of large-scale application rather than the lab level. And the exchange rate between US dollar and RMB was 6.3853 (the $27^{\text {th }}$ October, 2021). 


\section{Tables and Lists Section}

Table 1. Crystallographic data obtained from Rietveld refinements of the XRD patterns of the NVMP, NVMMP, NVAMP and NVTMP samples.

\begin{tabular}{|c|c|c|c|c|c|c|c|c|c|}
\hline & \multirow{2}{*}{\multicolumn{2}{|c|}{$\begin{array}{l}\text { Lattice Parameters } \\
\qquad(\AA)\end{array}$}} & \multirow{3}{*}{$\begin{array}{c}\text { Volume } \\
\AA^{3} \\
1479.03(3)\end{array}$} & \multicolumn{3}{|c|}{ Error Factor } & \multirow{3}{*}{$\begin{array}{c}\mathrm{V} / \mathrm{Mn} / \mathrm{M}-\mathrm{O}(\AA) \\
\mathrm{M}=\mathrm{Mg}, \mathrm{Al} \text { or } \mathrm{Ti} \\
2.1675(8)\end{array}$} & \multirow{3}{*}{$\begin{array}{l}\text { N1-O (A) } \\
2.5166(7)\end{array}$} & \multirow{3}{*}{$\begin{array}{l}\mathrm{Na2}-\mathrm{O}(\AA) \\
2.6338(8)\end{array}$} \\
\hline & & & & $\mathbf{w R}_{\mathrm{p}}$ & $\mathbf{R}_{\mathbf{p}}$ & $X^{2}$ & & & \\
\hline NVMP & $a=8.9198(2)$ & $c=21.4653(3)$ & & $4.71 \%$ & $3.46 \%$ & 1.647 & & & \\
\hline \multirow[t]{3}{*}{ NVMMP } & & & & & & & & & $2.6244(11$ \\
\hline & $a=8.9359(9)$ & $c=21.4557(1)$ & 1483.71(3) & $4.88 \%$ & $3.13 \%$ & 1.597 & $2.1047(11)$ & $2.4966(2)$ & \\
\hline & & & & & & & & & ) \\
\hline NVAMP & $a=8.9129(8)$ & $c=21.4679(8)$ & $1476.92(4)$ & $4.21 \%$ & $3.09 \%$ & 1.590 & $2.0807(7)$ & $2.4682(13)$ & $2.6307(1)$ \\
\hline NVTMP & $a=8.9091(4)$ & $c=21.4688(3)$ & $1475.72(7)$ & $4.93 \%$ & $3.35 \%$ & 1.699 & $2.1306(7)$ & $2.4883(2)$ & $2.6299(7)$ \\
\hline
\end{tabular}


Table S2. The main atomic position and occupation of the NVMP, NVAMP, NVMMP and NVTMP cathodes.

\begin{tabular}{|c|c|c|c|c|c|}
\hline Samples & Atom & $\mathbf{x}$ & $\mathbf{Y}$ & Z & Occupancy \\
\hline & Na1 & 0.00000 & 0.00000 & 0.00000 & $1.0421(2)$ \\
\hline & $\mathrm{Na} 2$ & $0.6331(9)$ & 0.00000 & 0.25000 & $0.9861(1)$ \\
\hline \multirow[t]{4}{*}{ NVMP } & V & 0.00000 & 0.00000 & $0.1478(6)$ & 0.5000 \\
\hline & $\mathrm{Mn}$ & 0.00000 & 0.00000 & $0.1478(6)$ & 0.5000 \\
\hline & $\mathrm{Na} 1$ & 0.00000 & 0.00000 & 0.00000 & $1.0410(9)$ \\
\hline & $\mathrm{Na} 2$ & $0.6569(3)$ & 0.00000 & 0.25000 & $0.9859(3)$ \\
\hline \multirow{5}{*}{ NVAMP } & V & 0.00000 & 0.00000 & $0.1495(3)$ & 0.4000 \\
\hline & $\mathrm{Mn}$ & 0.00000 & 0.00000 & $0.1495(3)$ & 0.5000 \\
\hline & $\mathrm{Al}$ & 0.00000 & 0.00000 & $0.1495(3)$ & 0.1000 \\
\hline & $\mathrm{Na} 1$ & 0.00000 & 0.00000 & 0.00000 & $1.0719(4)$ \\
\hline & $\mathrm{Na} 2$ & $0.6543(0)$ & 0.00000 & 0.25000 & $1.0346(1)$ \\
\hline \multirow{5}{*}{ NVMMP } & V & 0.00000 & 0.00000 & $0.1495(7)$ & 0.4000 \\
\hline & $\mathrm{Mn}$ & 0.00000 & 0.00000 & $0.1495(7)$ & 0.5000 \\
\hline & $\mathrm{Mg}$ & 0.00000 & 0.00000 & $0.1495(7)$ & 0.1000 \\
\hline & $\mathrm{Na} 1$ & 0.00000 & 0.00000 & 0.00000 & $1.0138(2)$ \\
\hline & $\mathrm{Na} 2$ & $0.6522(5)$ & 0.00000 & 0.25000 & $0.9277(2)$ \\
\hline \multirow{3}{*}{ NVTMP } & V & 0.00000 & 0.00000 & $0.1497(1)$ & 0.4000 \\
\hline & $\mathrm{Mn}$ & 0.00000 & 0.00000 & $0.1497(1)$ & 0.5000 \\
\hline & $\mathrm{Ti}$ & 0.00000 & 0.00000 & $0.1497(1)$ & 0.1000 \\
\hline
\end{tabular}


Table S3. The element composition of as-prepared samples by ICP

\begin{tabular}{ccccccccc}
\hline Elements & NVMP & NVAMP & NVMMP & NVTMP \\
& Actual & & Actual & Actual & \multicolumn{3}{c}{ Actual } \\
\hline $\mathrm{P}$ & $\mathbf{3}$ & $\mathbf{3}$ & $\mathbf{3}$ & $\mathbf{3}$ & $\mathbf{3}$ & $\mathbf{3}$ & 3 & $\mathbf{3}$ \\
$\mathrm{Na}$ & 4.0163 & $\mathbf{4}$ & 4.0970 & $\mathbf{4}$ & 4.1899 & $\mathbf{4 . 2}$ & 3.7689 & $\mathbf{3 . 8}$ \\
$\mathrm{V}$ & 0.9865 & $\mathbf{1}$ & 0.8097 & $\mathbf{0 . 8}$ & 0.8005 & $\mathbf{0 . 8}$ & 0.8110 & $\mathbf{0 . 8}$ \\
$\mathrm{Mn}$ & 1.1377 & $\mathbf{1}$ & 1.0180 & $\mathbf{1}$ & 0.9982 & $\mathbf{1}$ & 0.9945 & $\mathbf{1}$ \\
$\mathrm{Al}$ & 0 & & 0.1894 & $\mathbf{0 . 2}$ & 0 & $\mathbf{0}$ & 0 & $\mathbf{0}$ \\
$\mathrm{Mg}$ & 0 & & 0 & & 0.2013 & $\mathbf{0 . 2}$ & 0 & $\mathbf{0}$ \\
$\mathrm{Ti}$ & 0 & & 0 & & 0 & $\mathbf{0}$ & 0.2131 & $\mathbf{0 . 2}$ \\
\hline
\end{tabular}

The bolden typeface represents the nominal composition of compounds. 
Table S4. The comparison between the theoretical and real capacity for asprepared electrodes.

\begin{tabular}{|c|c|c|c|c|}
\hline Samples & NVMP & NVAMP & NVMMP & NVTMP \\
\hline Num. $\mathrm{Na}^{+}$ & 2 & 1.8 & 1.8 & 1.8 \\
\hline $\mathrm{M}_{\mathrm{w}}(\mathrm{g} / \mathrm{mol})$ & 482.75 & 477.96 & 482.02 & 477.54 \\
\hline $\mathrm{Q}_{\mathrm{T}}(\mathrm{mA} \mathrm{h} / \mathrm{g})$ & 111.04 & 100.93 & 100.08 & 101.02 \\
\hline $\mathrm{Q}_{\mathrm{R}}$ at $0.2 \mathrm{C}(\mathrm{mA} \mathrm{h} / \mathrm{g})$ & 104.5 & 94.5 & 87.6 & 92.4 \\
\hline \multicolumn{5}{|c|}{$\begin{array}{l}\text { Note: Num. } \mathrm{Na}^{+} \text {refers to the theoretical number of transferred electrons per formula in the } \\
\text { voltage range of } 2.5-3.8 \mathrm{~V} . M_{W} \text { represents the Molar mass of as-prepared cathodes. } Q_{T} \text { is } \\
\text { the theoretical capacity calculated by the following formula: } Q_{T}=\mathbf{N u m} . \mathrm{Na}^{+} \mathbf{F} / 3.6 \mathbf{M}_{\mathrm{W}} \text {. Where } \\
\mathrm{F} \text { is the Faraday constant }(\sim 96485 \mathrm{C} / \mathrm{mol}) . Q_{\mathrm{R}} \text { is the real capacity delivered by these } \\
\text { electrodes. }\end{array}$} \\
\hline
\end{tabular}


Table S5. The EIS impedance comparison between NVMP and NVAMP electrodes.

\begin{tabular}{ccccc}
\hline $\boldsymbol{R}_{\text {surf.+ct }}(\Omega)$ & $10^{\text {th }}$ & $100^{\text {th }}$ & $200^{\text {th }}$ & $500^{\text {th }}$ \\
\hline NVMP & 388 & 497 & 711 & 1694 \\
NVAMP & 270 & 371 & 499 & 547 \\
\hline
\end{tabular}


Table S6. Magnetic moments of $\mathrm{V}, \mathrm{Mn}$ and $\mathrm{Al}$ sites in $\mathrm{Na}_{\mathrm{x}} \mathrm{V}_{0.8} \mathrm{Al}_{0.2} \mathrm{Mn}\left(\mathrm{PO}_{4}\right)_{3}$ $(\mathrm{x}=2,3$, and 4$)$

\begin{tabular}{cccc}
\hline Compositions & \multicolumn{3}{c}{ Mag netic Moment $\left(\boldsymbol{\mu}_{\mathrm{B}}\right)$} \\
\hline & $\mathbf{V} \times 5$ & $\mathrm{Mn} \times 6$ & $\mathbf{A} \times 1$ \\
$\mathrm{Na}_{4} \mathrm{~V}_{0.8} \mathrm{Al}_{0.2} \mathrm{Mn}\left(\mathrm{PO}_{4}\right)_{3}$ & $1.90 \times 5$ & $4.67 \times 6$ & $0 \times 1$ \\
$\mathrm{Na}_{3} \mathrm{~V}_{0.8} \mathrm{Al}_{0.2} \mathrm{Mn}\left(\mathrm{PO}_{4}\right)_{3}$ & $1.06,1.07,1.07,1.09,1.09$ & $4.23,4.55,4.6,4.65,4.66,4.66$ & 0 \\
$\mathrm{Na}_{2} \mathrm{~V}_{0.8} \mathrm{Al}_{0.2} \mathrm{Mn}\left(\mathrm{PO}_{4}\right)_{3}$ & $1.04,1.04,1.05,1.05,0.07$ & $3.91,3.91,3.90,3.93,3.91,3.90$ & 0 \\
\hline
\end{tabular}


Table S7. The electrochemical performance comparison between NVMP cathode and the Mn-rich cathodes recently reported.

\begin{tabular}{|c|c|c|c|c|c|}
\hline Cathode & $\begin{array}{l}\text { Capacity } \\
\text { retention }\end{array}$ & $\begin{array}{c}\text { Voltage } \\
\text { range }\end{array}$ & $\begin{array}{c}\text { Rate } \\
\text { performance }\end{array}$ & Loading & Ref. \\
\hline $\mathrm{Na}_{4} \mathrm{~V}_{0.8} \mathrm{Al}_{0.2} \mathrm{Mn}\left(\mathrm{PO}_{4}\right)_{3}$ & $\begin{array}{c}80.1 \mathrm{~mA} \mathrm{~h} \mathrm{~g}^{-1} \text { at } \\
1000^{\text {th }} \text { cycle at } 5 \mathrm{C} \\
(92 \% \text { retention }) \\
74 \mathrm{~mA} \mathrm{~h} \mathrm{~g}^{-1} \text { at } \\
2000^{\text {th }} \text { cycle at } 20 \mathrm{C} \\
(87 \% \text { retention })\end{array}$ & $2.5-3.8 \mathrm{~V}$ & $\begin{array}{l}85.0 \mathrm{~mA} \mathrm{~h} \mathrm{~g}^{-1} \text { at } 10 \mathrm{C} \\
84.8 \mathrm{~mA} \mathrm{~h} \mathrm{~g}^{-1} \text { at } 20 \mathrm{C} \\
84.7 \mathrm{~mA} \mathrm{~h} \mathrm{~g}^{-1} \text { at } 30 \mathrm{C} \\
84.2 \mathrm{~mA} \mathrm{~h} \mathrm{~g}^{-1} \text { at } 40 \mathrm{C}\end{array}$ & $>5.5 \mathrm{mg} / \mathrm{cm}^{2}$ & \\
\hline $\mathrm{Na}_{4} \mathrm{MnV}\left(\mathrm{PO}_{4}\right)_{3}$ & $\begin{array}{c}93 \mathrm{~mA} \mathrm{~h} \mathrm{~g}^{-1} \text { at } \\
500^{\text {th }} \text { cycle at } 5 \mathrm{C} \\
(91.4 \% \text { retention }) \\
53.7 \mathrm{~mA} \mathrm{~h} \mathrm{~g}^{-1} \text { at } \\
4000^{\text {th }} \text { cycle at } 20 \mathrm{C} \\
(68.8 \% \text { retention })\end{array}$ & $\begin{array}{l}2.5- \\
3.8 \mathrm{~V}\end{array}$ & $\begin{array}{l}107.3 \mathrm{~mA} \mathrm{~h} \mathrm{~g}^{-1} \text { at } 1 \mathrm{C} \\
95.9 \mathrm{~mA} \mathrm{~h} \mathrm{~g}^{-1} \text { at } 5 \mathrm{C} \\
88.1 \mathrm{~mA} \mathrm{~h} \mathrm{~g}^{-1} \text { at } 10 \mathrm{C} \\
77.3 \mathrm{~mA} \mathrm{~h} \mathrm{~g}^{-1} \text { at } 20 \mathrm{C} \\
60.1 \mathrm{~mA} \mathrm{~h} \mathrm{~g}^{-1} \text { at } 50 \mathrm{C}\end{array}$ & $\sim 1.8 \mathrm{mg} / \mathrm{cm}^{2}$ & 1 \\
\hline $\mathrm{Na}_{4} \mathrm{MnV}\left(\mathrm{PO}_{4}\right)_{3}$ & $\begin{array}{l}90 \mathrm{~mA} \mathrm{~h}^{-1} \text { after } \\
1000 \text { cycles at } 1 \mathrm{C} \\
\text { (89\% retention) }\end{array}$ & $2.5-3.8 \mathrm{~V}$ & $\begin{array}{l}101 \mathrm{~mA} \mathrm{~h} \mathrm{~g}^{-1} \text { at } 1 \mathrm{C}^{-1} \\
98 \mathrm{~mA} \mathrm{~h} \mathrm{~g}^{-1} \text { at } 2 \mathrm{C} \\
90 \mathrm{~mA} \mathrm{~h} \mathrm{~g}^{-1} \text { at } 10 \mathrm{C}\end{array}$ & I & 2 \\
\hline $\mathrm{Na}_{4} \mathrm{Mn}_{0.75} \mathrm{Mg}_{0.25} \mathrm{~V}\left(\mathrm{PO}_{4}\right)_{3}$ & $\begin{array}{l}88 \mathrm{~mA} \mathrm{~h} \mathrm{~g}^{-1} \text { after } 100 \\
\text { cycles at } 1 \mathrm{C} \\
\text { (96\% retention) }\end{array}$ & $\begin{array}{l}2.75- \\
3.8 \mathrm{~V}\end{array}$ & $\begin{array}{l}90 \mathrm{~mA} \mathrm{~h} \mathrm{~g}^{-1} \text { at } 1 \mathrm{C}^{-} \\
85 \mathrm{~mA} \mathrm{~h} \mathrm{~g}^{-1} \text { at } 2 \mathrm{C} \\
80 \mathrm{~mA} \mathrm{~h} \mathrm{~g}^{-1} \text { at } 5 \mathrm{C}\end{array}$ & $\sim 2 \mathrm{mg} / \mathrm{cm}^{2}$ & 3 \\
\hline $\mathrm{Na}_{4} \mathrm{VMn}_{0.9} \mathrm{Cu}_{0.1}\left(\mathrm{PO}_{4}\right)_{3}$ & $\begin{array}{c}79 \mathrm{~mA} \mathrm{~h} \mathrm{~g}^{-1} \text { after } \\
450^{\text {th }} \text { cycle at } 1 \mathrm{C} \\
(90 \% \text { retention }) \\
68 \mathrm{~mA} \mathrm{~h} \mathrm{~g}^{-1} \text { at } \\
3000^{\text {th }} \text { cycle at } 30 \mathrm{C} \\
(86 \% \text { retention })\end{array}$ & $2.4-3.8 \mathrm{~V}$ & $\begin{array}{l}103 \mathrm{~mA} \mathrm{~h}^{-1} \text { at } 1 \mathrm{C} \\
96 \mathrm{~mA} \mathrm{~h} \mathrm{~g}^{-1} \text { at } 2 \mathrm{C} \\
90 \mathrm{~mA} \mathrm{~h} \mathrm{~g}^{-1} \text { at } 5 \mathrm{C} \\
82 \mathrm{~mA} \mathrm{~h} \mathrm{~g}^{-1} \text { at } 10 \mathrm{C} \\
77 \mathrm{~mA} \mathrm{~h} \mathrm{~g}^{-1} \text { at } 20 \mathrm{C} \\
72 \mathrm{~mA} \mathrm{~h} \mathrm{~g}^{-1} \text { at } 30 \mathrm{C} \\
68 \mathrm{~mA} \mathrm{~h}^{-1} \text { at } 40 \mathrm{C}\end{array}$ & l & 4 \\
\hline $\mathrm{Na}_{3.75} \mathrm{~V}_{1.25} \mathrm{Mn}_{0.75}\left(\mathrm{PO}_{4}\right)_{3}$ & $\begin{array}{l}85.3 \mathrm{~mA} \mathrm{~h}^{-1} \text { after } \\
100^{\text {th }} \text { cycle at } 1 \mathrm{C} \text {. } \\
(87 \% \text { retention }) \\
84.5 \mathrm{~mA} \mathrm{~h} \mathrm{~g}^{-1} \text { at } \\
100^{\text {th }} \text { cycle at } 5 \mathrm{C} \\
(96 \% \text { retention })\end{array}$ & $\begin{array}{l}2.75- \\
3.8 \mathrm{~V}\end{array}$ & $\begin{array}{l}104 \mathrm{~mA} \mathrm{~h} \mathrm{~g}^{-1} \text { at } 0.1 \mathrm{C} \\
102 \mathrm{~mA} \mathrm{~h} \mathrm{~g}^{-1} \text { at } 0.2 \mathrm{C} \\
101 \mathrm{~mA} \mathrm{~h} \mathrm{~g}^{-1} \text { at } 0.5 \mathrm{C} \\
100 \mathrm{~mA} \mathrm{~h} \mathrm{~g}^{-1} \text { at } 1 \mathrm{C} \\
95 \mathrm{~mA} \mathrm{~h} \mathrm{~g}^{-1} \text { at } 2 \mathrm{C} \\
89.4 \mathrm{~mA} \mathrm{~h} \mathrm{~g}^{-1} \text { at } 5 \mathrm{C}\end{array}$ & $\sim 3 \mathrm{mg} / \mathrm{cm}^{2}$ & 5 \\
\hline $\mathrm{Na}_{3.85} \mathrm{MnV}\left(\mathrm{PO}_{3.95} \mathrm{~F}_{0.05}\right)_{3}$ & $\begin{array}{c}80 \mathrm{~mA} \mathrm{~h} \mathrm{~g}^{-1} \text { after } 500 \\
\text { cycles at } 1 \mathrm{C}\end{array}$ & $2.5-3.8 \mathrm{~V}$ & $\begin{array}{l}108 \mathrm{~mA} \mathrm{~h} \mathrm{~g}^{-1} \text { at } 0.1 \mathrm{C} \\
98 \mathrm{~mA} \mathrm{~h} \mathrm{~g}^{-1} \text { at } 0.2 \mathrm{C}\end{array}$ & $1.2-1.5 \mathrm{mg} / \mathrm{cm}^{2}$ & 6 \\
\hline
\end{tabular}




\section{References in the Table S7:}

1. Adv. Energy Mater. 2018, 8, 1801418;

2. Nano Lett. $2016,16,7836-7841$;

3. Small Methods 2019, 3, 1800183;

4. J. Mater. Chem. A, 2020, 8, 12055-12068;

5. Adv. Energy Mater. 2019, 1902918;

6. Energy Storage Materials. 2021, 42, 307-316. 
Table S8. The raw materials cost of NVMP, NVAMP, $\mathrm{N}_{\mathrm{ex}} \mathrm{VMP}$ and $\mathrm{N}_{\mathrm{ex}} \mathrm{VAMP}$ cathodes based on current market prices.

\begin{tabular}{|c|c|c|c|c|c|c|c|c|}
\hline Raw materials & Price $/ \$ \mathrm{~kg}^{-1}$ & $\begin{array}{l}\text { Purity } \\
\text { /wt } \%\end{array}$ & Suppliers & $\begin{array}{c}\mathbf{k g} \\
/ \mathrm{kg} \mathrm{NVP}\end{array}$ & $\begin{array}{c}\text { kg } \\
/ \mathrm{kg} \mathrm{NVMP}\end{array}$ & $\begin{array}{c}\text { kg } \\
/ \mathrm{kg} \text { NVAMP }\end{array}$ & $\begin{array}{c}\mathbf{k g} \\
/ \mathrm{kg} \mathrm{N} \text { ex VMP) }\end{array}$ & $\begin{array}{c}\mathbf{k g} \\
/ \mathrm{kg} \mathrm{N}_{\mathrm{ex}} \text { VAMP) }\end{array}$ \\
\hline $\mathrm{Na}_{2} \mathrm{CO}_{3}$ & 0.232 & 99.2 & $\begin{array}{c}\text { Jinan chunlufu Trading Co., } \\
\text { Ltd }\end{array}$ & 0 & 0.1106 & 0.1117 & 0.1313 & 0.1326 \\
\hline $\mathrm{V}_{2} \mathrm{O}_{3}$ & 23.458 & 99.0 & Pangang Group Co., Ltd & 0.3322 & $0.1584^{-}$ & 0.1280 & 0.1253 & 0.0949 \\
\hline $\mathrm{Al}_{2} \mathrm{O}_{3}$ & 1.392 & 98.0 & Chemical Co., Ltd & 0 & 0 & 0.0218 & 0 & 0.0215 \\
\hline $\mathrm{MnCO}_{3}$ & 0.7733 & 99.0 & $\begin{array}{l}\text { Hubei xinrunde Chemical } \\
\text { Co., Ltd }\end{array}$ & 0 & 0.2404 & 0.2429 & 0.2854 & 0.2882 \\
\hline $\mathrm{NaH}_{2} \mathrm{PO}_{4} \cdot 12 \mathrm{H}_{2} \mathrm{O}$ & 1.160 & 99.0 & $\begin{array}{l}\text { LangfangQianyao Chemical } \\
\text { Reagent Co., Ltd }\end{array}$ & 2.3812 & 2.2474 & 2.2699 & 2.2232 & 2.2446 \\
\hline $\mathrm{C}_{6} \mathrm{H}_{12} \mathrm{O}_{6}$ & 0.433 & 98.0 & $\begin{array}{l}\text { Hubei xinrunde Chemical } \\
\text { Co., Ltd }\end{array}$ & $\sim 0.8068$ & $\sim 0.7614$ & $\sim 0.7690$ & $\sim 0.7532$ & $\sim 0.7604$ \\
\hline & & & Product cost $/ \$ \mathrm{~kg}^{-1}$ & 11.07 & $6.86^{-}$ & $6.21^{-}$ & $6.10^{-}$ & $5.44^{-}$ \\
\hline
\end{tabular}

\section{Note:}

1. The price data was collected in October, 2021 from the normal purchasing website https://china.guidechem.com or https://www.1688.com.

2. The final product rice only considers the price of the raw materials. And these raw materials adopted the easily-prepared metal oxides or carbonates etc. from the perspective of large-scale application rather than the lab level.

3. $\mathrm{Na}_{2} \mathbf{C O}_{3}$ : Anhydrous sodium carbonate, $105.99 \mathrm{~g} / \mathrm{mol} ; \mathbf{V}_{2} \mathbf{O}_{3}$ : Vanadium trioxide, $149.88 \mathrm{~g} / \mathrm{mol} ; \mathbf{A l}_{2} \mathbf{O}_{3}$ : Aluminium oxide, $101.96 \mathrm{~g} / \mathrm{mol} ; \mathbf{M n C O}_{3}$ : Manganese carbonate, $114.95 \mathrm{~g} / \mathrm{mol} ; \mathbf{N a H}_{\mathbf{2}} \mathbf{P O}_{\mathbf{4}} \cdot \mathbf{1 2} \mathbf{H}_{\mathbf{2}} \mathbf{O}$ : Sodium dihydrogen phosphate dodecahydrate, $358.14 \mathrm{~g} / \mathrm{mol} \mathrm{C}_{6} \mathrm{H}_{12} \mathrm{O}_{6}$ : Anhydrous glucose, $180.16 \mathrm{~g} / \mathrm{mol}$.

4. The exchange rate between US dollar and RMB was 6.3853 (the $27^{\text {th }}$ October, 2021). 